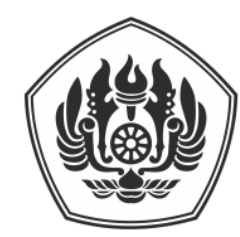

\author{
Padjadjaran Journal of International Law \\ ISSN: 2549-2152, EISSN: 2549-1296 \\ Volume 3, Number 2, June 2019
}

\title{
The Interrelation of Forced Eviction and the Right to Development
}

\author{
Difa Ghiblartar Gastina, ${ }^{*}$ Irawati Handayani**
}

\begin{abstract}
Development is one of the most common reasons to evict inhabitant forcibly. This happens because individuals or communities are placed as objects of development, causing the closure of participation space in development. In the perspective of human rights, development is claimed as a right, which every human being has the right to participate, contribute, and receive benefits for everything that results from development. This study aims to understand the perspective of the right to development towards forced evictions and the implementation od state obligation on the right to development at the national level. The study reveals that based on the principles in the right to development (such as holistic development;placement of humans as the central subject of development as well as participation in the development process) can protect individuals or communities from forced evictions. Futhermore, to ensure the fulfillment, state has key role to implement the right to development at the national level.
\end{abstract}

Keywords: Forced Eviction, Human Rights, Right to Development.

\section{Keterkaitan Antara Penggusuran Paksa dan Hak Atas Pembangunan}

\begin{abstract}
Abstrak
Pembangunan merupakan salah-satu alasan paling umum penyebab terjadinya penggusuran paksa. Hal ini dikarenakan individu atau masyarakat ditempatkan sebagai objek pembangunan yang menyebabkan tertutupnya ruang partisipatif dalam pembangunan tersebut. Dalam perspektif hak asasi manusia, pembangunan diklaim sebagai hak dimana setiap orang berhak untuk berpartisipasi, berkontribusi dan menerima manfaat hasil pembangunan. Penelitian ini bertujuan untuk mengetahui perspektif hak atas pembangunan terhadap penggusuran paksa, serta bagaimana kewajiban Negara dalam menerapkan hak tersebut ditingkat nasional. b Berdasarkan analisis terhadap prinsip-prinsip dalam hak atas pembangunana seperti pembangunan yang holistik; penempatan manusia sebagai subjek sentral dari pembangunan dan juga partisipasi dalam proses pembangunan dapat melindungi individu atau masyarakat dari penggusuran paksa. Untuk menjamin pemenuhannya, Negara dalam menerapkan hak atas pembangunan ditingkat nasional.
\end{abstract}

Kata Kunci: Hak Asasi Manusia, Hak atas Pembangunan, Penggusuran Paksa.

** Lecturer and Researcher at International Law Department, Universitas Padjadjaran, Jl. Dipati Ukur No. 35, Bandung, irawati@unpad.ac.id. 


\section{A. INTRODUCTION}

The tendency of state to focus on building physical infrastructure by mainstreaming technocratic approach is feared to be the cause of the abandonment of human rights approach in the development process. ${ }^{1}$ In Nairobi, Kenya, evictions by the government threatened about 300,000 Nairobi residents living in informal settlements. ${ }^{2}$ In the Dominican Republic, development projects related to urbanization, such as road construction or development of land for tourism, led to forced evictions. ${ }^{3}$

Forced eviction is a violation of human rights, which not only causes the violation of the right to residence, but also impacts on the spectrum of other human rights. ${ }^{4}$ Forced evictions situating individuals or communities as objects of development, which causes the closure of participation space in development. This is inversely proportional to the concept of development, which covers the aspects of human rights. Development is claimed as a human right after the adoption of the Declaration of the Right to Development in 1986.

The inclusion not only accommodates the demands of developing countries for a just international order which in line with the objectives of the New International Economic Order (NIEO), but also gives significant influence on the discourse of

Atip Latipulhayat, "Merawat Hak Asasi Manusia", Editorial Padjadjaran Jurnal Ilmu Hukum, Volume 1 No 2 August 2014, p. ii.

2 UN Habitat, "Forced "Forced Evictions: Global Crisis, Global Solutions", A Review of the Status of Forced Evictions Globally Through the Work of the Advisory Group on Forced Evictions, Un Habitat and Other International Actors, p. 36

$3 \quad$ Ibid, p. 37

4 The resolution of the UN Human Rights Commission Number 1993/77 and 2004/28 states that forced evictions not only cause violations of the right to housing, but also affect the spectrum of other human rights.

5 Arjun Sengupta, "On the Theory and Practice of the Right to Development", Human Rights Quarterly, Vol. 24, No. 4, 2002, p 838

6 Irawati Handayani, Justiciability of Economic, Social and Cultural Rights in International Law and Its human rights. ${ }^{5}$ The element of the right to development, such as collective rights, has surpassed the traditional view of human rights that emphasizes individual rights. ${ }^{6}$ The right to development is also considered as a unitification civil and political rights as well as economic, social, and cultural rights. ${ }^{7}$ This is because it recognizes that human rights are inseparable and interdependent. ${ }^{8}$ The right to development also gives hope for vulnerable groups, especially the poor who are vulnerable to foced eviction, to be involved in the development process. The right to development is an irrevocable right whereall people have the right to participate and contribute to the enjoyment of economic, social, cultural, and political development, hence human rights and fundamental freedoms can be fully realized. ${ }^{9}$ Thus, it can prevent the poor from being placed as object of development.

Accordingly, there is a possibility to analyze forced evictions in the perspective of the right to developmentbecause the involvement of of individuals or communities in the development process is an important element in preventing forced evictions. In addition, the right to development also aims to fulfill human rights and fundamental freedoms. Therefore, development must lead to the realization of human rights which based on

Implementation in Indonesia, Jurnal Yustisia, Vol. 7 No. 3, 2018, p. 452.

Arjun Sengupta, "On the Theory and Practice of the Right to Development", Op.cit, p. 840.

8 Article 6 paragraph (2) of the Declaration of the Right to Development. "All human rights and fundamental freedoms are indivisible and interdependent; equal attention and urgent consideration should be given to the implementation, promotion and protection of civil, political, economic, social and cultural rights.".

Article 1 paragraph (1) of the Declaration of the Right to Development. "The right to development is an inalienable human right by virtue of which every human person and all peoples are entitled to participate in, contribute to, and enjoy economic, social, cultural and political development in which all human rights and fundamental freedoms can be fully realized". 
the principles of equity and social justice. ${ }^{10}$ For this reason, state must avoid the development that lead to the violations of human rights.

Based on these descriptions, the study tried to reveal the perspective of the right to development towards forced eviction and the implementation of state obligation on the right to development at the national level. In this article, the author tries to provide another alternative in analysing forced evictions using the perspective of the right to development. The author will evaluate international legal instruments in related to the right to development and other instruments in related to forced evictions.

\section{B. RIGHT TO DEVELOPMENT AS A HUMAN RIGHT}

Donnelly conceptualizes the traditional view of human rights as something inherent in humans, sourced from natural rights, and not given by the community. ${ }^{11}$ The paradigm of placing human rights as an individual right is associated with negative freedom. ${ }^{12}$ Thus, according to Donnelly, collective rights such as the right to development is not seen as human rights. Instead, the right to development is no more than an individual right. It is only a "right to pursue full personal development along all major dimensions of human life", this type of right is a summary of traditional rights. ${ }^{13}$ This opinion is certainly different from the development of human rights that places the right to development in the third generation of human rights. The substance

10 Khursid Iqbal, The Right to Development in International Law: The Case of Pakistan, Abingdon, Routledge Research in Human Rights Law, 2009, p. 59.

11 Jack Donnely in Rhona K. M. Smith, et.al, Hukum Hak Asasi Manusia, Yogyakarta, PUSHAM UII, 2008, p. 11.

12 Arjun K. Sengupta, "Conceptualizing the right to development for the twenty-first century" dalam buku Realizing the Right to Development: Essays in Commemoration of 25 Years of the United Nations Declaration on the Right to Development, New York and Geneva: United Nations Publication, 2013, p. 74.

13 Donnelly in Patrick Macklem The Sovereignty of Human Rights, New York: Oxford University Press, 2015, p. 195. transcends traditional rights, one of which is collective rights. The view that sees human rights only as an individual right, according to Iqbal, is based on Aston's excessively individualistic approach to human rights. ${ }^{14}$ For Iqbal this view does not consider social and economic conditions. ${ }^{15}$

Unlike Jack Donnelly's view, experts in developing countries view the right to development as human right. Sengupta states that the traditional argument could be refuted by referring to the substance of human rights contained in the literature such as the Universal Declaration of Human Rights (UDHR). It contains elements of human rights, which exceeded the principles of natural rights. ${ }^{16} \mathrm{He}$ argues it is due to a pluralistic In international legal basis, the Universal Declaration of Law does not only contain natural rights but also economic, social, and cultural rights. ${ }^{17}$ Regarding collective rights and individual rights, Sengupta reveals that there is no reason to distinguish between the two, as long as it can determine the obligation for the bearer to fulfill and to secure these rights. ${ }^{18}$ Also, the dichotomy between positive and negative obligations cannot be justified because the implementation of both rights requires negative (prevention) and positive (promotion or protective) obligations. ${ }^{19}$ In this case, according to Sengupta, it is difficult to consider only civil and political rights as human rights, while economic and social as well as collective rights are not considered as human rights. ${ }^{20}$

Meanwhile, M'baye discusses the debate between human rights and people rights, explains that although

14 Khursid Iqbal, Op.Cit, p. 52

15 Ibid.

16 Arjun K. Sengupta, "Conceptualizing the right to development for the twenty-first century" dalam buku Realizing the Right to Development: Essays in Commemoration of 25 Years of the United Nations Declaration on the Right to Development, Loc.cit.

17 Ibid.

18 Ibid.

19 Ibid.

20 Ibid. 
community/people rights are collective, they are also individual because individuals are the ultimate beneficiaries of collective rights (the ultimate beneficiary of rights). ${ }^{21}$ It similar to the opinion of Abi-Saab who views the right to development as collective and individual rights. ${ }^{22}$

The definition of the right to development is an inalienable human right by virtue of which every human person and all peoples are entitled to participate in, contribute to, and enjoy economic, social, cultural and political development, in which all human rights and fundamental freedoms can be fully realized. ${ }^{23}$ According to Sengupta, the definition has three principles as follows. ${ }^{24}$

1. There is an inalienable human right that is called the right to development.

2. There is a particular process of economic, social, cultural, and political development, in which all human rights and fundamental freedoms can be fully realized.

3. The right to development is a human right by virtue of which every human person and all peoples are entitled to participate in, contribute to and enjoy that particular process of development.

Sengupta explains these three principles in detail as follows: ${ }^{25}$

1. The first principle affirms the right to development as an inalienable human right and, as such, the right cannot be taken or bargained away.

2. The second principle defines a process of development in terms of the realization of "human rights," which are enumerated in the Universal Declaration and other

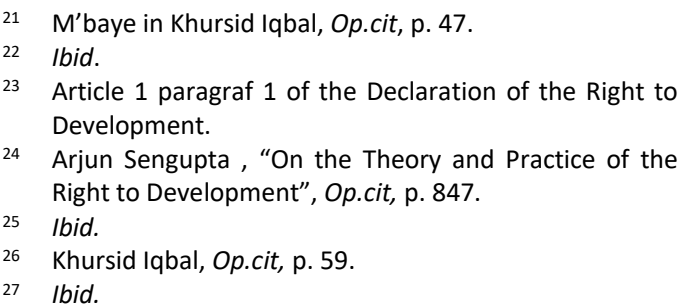

human rights instruments adopted by United Nations and regional bodies.

3. The third principle defines the right to that process of development in terms of claims or entitlements of rights holders, which duty bearers must protect and promote.

Sengupta states that the right to development is the right to the process of development. In this case, development must be a process that leads to the realization of human rights. ${ }^{26}$ In addition, the development process must also lead to the principles of equity and social justice. ${ }^{27}$ It is based on several articles ${ }^{28}$ of the Declaration of the Right to Development, outlining the intention that human rights are the right to the development process. ${ }^{29}$ According to Osmani, the right to development must not be defined exclusively as a right to the development process. ${ }^{30}$ Osmani argues that this view makes the right to development only valuable instrumental and ignore the results (such as equity and sustainability) that has intrinsic value in the concept of the right to development. ${ }^{31}$ Osmani proposes an alternative formulation of the right to development, which is consistent with definition the Right to Development. It includes the right to a process and the right to outcomes. ${ }^{32}$

"(1) The right to development is the right of everyone to enjoy the full array of socio-economic-cultural as well as civil-political rights equitably and sustainably and (2) through a process that satisfies the principles of participation, non-discrimination, transparency and accountability."

28 Article I paragraph 1 , article 2 paragraph 3, article 6 , article 8 of the of the Declaration of the Right to Development. See Iqbal's footnote, Ibid.

29 Arjun Sengupta, "On the Theory and Practice of the Right to Development", Op.cit, p. 848.

30 Osmani in Khursid Iqbal, Op.cit, p. 60.

31 Ibid.

2 Ibid, p. 61. 
In addition, the definition of the Right to Development reveals two approaches of development. First, development is a comprehensive concept, which creates a supportive condition for the realization of all human rights and fundamental freedoms, Second, every human being and all people have the right to participate, contribute, and enjoy the development. ${ }^{33}$

\section{INTERNATIONAL LAW INSTRUMENT IN RELATED TO THE RIGHT TO DEVELOPMENT AND FORCED EVICTIONS}

1. Declaration on The Right to Development

The main concept of the Declaration is the link between respect for human rights and development; the important role of participation in development and in the realization of human rights; the role of individuals as subjects, not objects of development; the creation and promotion of international conditions that support the realization of the right to development; the interrelation and interdependence of civil and political rights and economic, social and cultural rights; and, principles of equity and social justice. ${ }^{34}$ One of the influences of the right to development on the concept of development is the change of the notion of development to be holistic. The definition of holistic development is stated in the Preamble of Paragraph 2 of the Declaration of the Right to Development:

"Development is a
comprehensive economic,
social, cultural and political
process, which aims at the
constant improvement of the
well-being of the entire
population and of all

$33 \quad$ Ibid, p. 9.

34 Taznara Kunanayakam, "Annotations to the Declaration on the Right to Development and related United Nations system instruments, resolutions and reports" individuals on the basis of their active, free and meaningful participation in development and in the fair distribution of benefits resulting therefrom".

The Declaration of the Right to Development also recognizes the importance of respecting and promoting human rights, as contained in Article 6 of the Declaration of the Right to Development:

1) All States should cooperate with a view to promoting, encouraging and strengthening universal respect for and observance of all human rights and fundamental freedoms for all without any distinction as to race, sex, language or religion.

2) All human rights and fundamental freedoms are indivisible and interdependent; equal attention and urgent consideration should be given to the implementation, promotion and protection of civil, political, economic, social and cultural rights.

3) States should take steps to eliminate obstacles to development resulting from failure to observe civil and political rights, as well as economic, social and cultural rights.

Article 2 Paragraph 1 of the Declaration on the Right to Development states "the human person is the active participant and the beneficiary of the right to development". In addition, Article 1 paragraph 1 of the Declaration of the

(HR/RD/1990/ CONF.1), Global Consultation on the Realization of the Right to Development as a Human Right, p. 1. 
Right to Development states that individuals and peoples have the right to participate in development process. ${ }^{35}$ Then, Article 2 paragraph 3 states as follows.

"States have the right and the duty to formulate appropriate national development policies that aim at the constant improvement of the well-being of the entire population and of all individuals, on the basis of their active, free and meaningful participation in development and in the fair distribution of the benefits resulting therefrom."

Article 8 paragraph 2, "States should encourage popular participation in all spheres as an important factor in development and in the full realization of all human rights." The Declaration on the Right to Development give special attention to women, Article 8 paragraph 1 states "...women have an active role in the development process."

Humans are stakeholders of the right to development, both individually and collectively. This is related to the content of the Declaration of the Right to Development, which consists of individual and collective rights. As

35 Article 1 paragraph 1 of the Declaration of the Right to Development, "The right to development is an inalienable human right by virtue of which every human person and all peoples are entitled to participate in, contribute to, and enjoy economic, social, cultural and political development, in which all human rights and fundamental freedoms can be fully realized."

36 Khursid lqbal, Op.cit, p. 57.

37 Frequently Asked Questions on the Right to Development, (Fact Sheet No. 37), p. 3.

38 Khursid lqbal, Op.cit, p. 58.

39 Frequently Asked Questions on the Right to Development (Fact Sheet No. 37), Loc.cit. Article 1 paragraph 2 of the Declaration of the Right to Development, "The human right to development also implies the full realization of the right of peoples to selfdetermination, which includes, subject to the relevant provisions of both International Covenants on Human Rights, the exercise of their inalienable right to full sovereignty over all their natural wealth and resources." Article 5 of the Declaration of the Right to Development, "States shall take resolute steps to eliminate the massive and flagrant violations of the human rights of peoples individual rights is confirmed in article 1 (1). According to Iqbal, the article must be read by relating it to other articles, such as Articles 2, 6, and 8. Then again, Articles 2 and 8 generally describe the aims and the objectives of the right to development. ${ }^{36}$ As a collective right is mentioned in article 1 paragraph 1 that mentions all people and Article 2 paragraph 3 as "entire population". ${ }^{37}$ With regard to the collective form of the right to development, the promotion of new international economic orders has major influence in the formation of the collective right. ${ }^{38}$ It is also closely related to the right to selfdetermination, including the right to full sovereignty of natural resources, as contained in article 1 paragraph 2 and article 5 of the Declaration on the Right to Development. ${ }^{39}$

In the Declaration of the Right to Development, state's obligation to implement the right to development is divided into internal and external dimensions. ${ }^{40}$ The internal dimension relates to the implementation of the right to development in its jurisdiction or at the national level, ${ }^{41}$ this is contained in article 2 paragraph 3 and article 8 paragraph $1 .^{42}$ The external dimension is the implementation of the

and human beings affected by situations such as those resulting from apartheid, all forms of racism and racial discrimination, colonialism, foreign domination and occupation, aggression, foreign interference and threats against national sovereignty, national unity and territorial integrity, threats of war and refusal to recognize the fundamental right of peoples to selfdetermination."

40 Nienke van der Have,"The Right to Development and State Responsibility", Amsterdam Law School Legal Studies Research Paper No. 2013-23, p. 4. Reads Article 3 paragraph 1 of the Declaration of the Right to Development, "States have the primary responsibility for the creation of national and international conditions favourable to the realization of the right to development."

41 lbid.

42 Article 2 paragraph 3 of the Declaration of the Right to Development, "States have the right and the duty to formulate appropriate national development policies that aim at the constant improvement of the well-being of the entire population and of all individuals, on the basis of their active, free and meaningful participation 
right to development at the international level, ${ }^{43}$ this is contained in article 3 paragraph 2 and 3 , article 4 paragraph 1 and paragraph 2, and article7. ${ }^{44}$ Article $6,9^{45}$, and $10^{46}$ of the Declaration of the Right to Development states that the implementation of the right to development must respect human rights completely, either civil or political rights; and economic, social, and cultural rights.

\section{Forced eviction as a Violation of} Human Rights and Its Relationship with Development

Forced evictions described as the permanent or temporary removal

in development and in the fair distribution of the benefits resulting therefrom." Article 8 paragraph 1 of the Declaration of the Right to Development, "States should undertake, at the national level, all necessary measures for the realization of the right to development and shall ensure, inter alia, equality of opportunity for all in their access to basic resources, education, health services, food, housing, employment and the fair distribution of income. Effective measures should be undertaken to ensure that women have an active role in the development process. Appropriate economic and social reforms should be carried out with a view to eradicating all social injustices."

43 Nienke van der Have, Loc.cit.

44 Article 3 paragraph 2 of the Declaration of the Right to Development "The realization of the right to development requires full respect for the principles of international law concerning friendly relations and cooperation among States in accordance with the Charter of the United Nations." Article 3 paragraph 3 of the Declaration of the Right to Development, "States have the duty to co-operate with each other in ensuring development and eliminating obstacles to development. States should realize their rights and fulfil their duties in such a manner as to promote a new international economic order based on sovereign equality, interdependence, mutual interest and co-operation among all States, as well as to encourage the observance and realization of human rights." Article 4 paragraph 1 of the Declaration of the Right to Development. "States have the duty to take steps, individually and collectively, to formulate international development policies with a view to facilitating the full realization of the right to development.". Article 4 paragraph 2, "Sustained action is required to promote more rapid development of developing countries. As a complement to the efforts of developing countries, effective international co-operation is essential in providing these countries with appropriate means and facilities to foster their comprehensive development." Article 7 of the Declaration of the Right to Development, "All States should promote the establishment, against their will of individuals, families and/or communities from the homes and/or land, which they occupy, without the provision of, and access to, appropriate forms of legal or other protection. ${ }^{47}$ Forced eviction has become a global epidemic. asTherefore it catch international legal attention. ${ }^{48}$

The concern of the international community on the issue of forced evictions is based on the consequences of human rights violations. The resolutions of the UN Human Rights Commission Number $1993 / 77^{49}$ and $2004 / 28^{50}$ state that forced evictions does not only cause violations on the right to housing but also affect the other spectrum of human rights. Other

maintenance and strengthening of international peace and security and, to that end, should do their utmost to achieve general and complete disarmament under effective international control, as well as to ensure that the resources released by effective disarmament measures are used for comprehensive development, in particular that of the developing countries."

45 Article 9 paragraph 1 of the Declaration of the Right to Development, "All the aspects of the right to development set forth in the present Declaration are indivisible and interdependent and each of them should be considered in the context of the whole." ${ }^{45}$ Article 9 paragraph 2 of the Declaration of the Right to Development, "Nothing in the present Declaration shall be construed as being contrary to the purposes and principles of the United Nations, or as implying that any State, group or person has a right to engage in any activity or to perform any act aimed at the violation of the rights set forth in the Universal Declaration of Human Rights and in the International Covenants on Human Rights."

46 Article 10 of the Declaration of the Right to Development, "Steps should be taken to ensure the full exercise and progressive enhancement of the right to development, including the formulation, adoption and implementation of policy, legislative and other measures at the national and international levels."

47 General Comment No. 7: The right to adequate housing (Art.11.1), paragraph 3.

48 Malcolm Langford and Jean du Plessis, "Dignity in the Rubble? Forced Evictions and Human Rights Law", p. 1. https://www.jus.uio.no/ior/english/people/aca/malcol $\mathrm{ml} /$ dignity-in-the-rubble---human-rights-law-andforced-evictions.pdf.

49 "the practice of forced evictions constitutes a gross violation of human rights, in particular the right to adequate housing.".

50 "the practice of forced eviction that is contrary to laws that are in conformity with international human rights standards constitutes a gross violation of a broad range of human rights, in particular the right to adequate housing." 
international legal instruments that Forced Evictions, Fact Sheet No. 25/Rev.1. The Fact Sheet explaining the relationship between forced evictions and human rights violations. ${ }^{51}$ The same statement is emphasized earlier in the CESCR General Comment Number 4: The Right to Adequate Housing. It says that everyone must be legally protected from forced eviction. ${ }^{52} \mathrm{~A}$ more detail information is contained in the General Comment Number 7: The right to adequate housing (Art.11.1): forced evictions. However, it mentions that if must uphold and respect human rights. ${ }^{53}$ Based on this, evictions are not prohibited but international law warns that eviction must be the last choice. If it cannot be avoided then there are conditions that must be fulfilled.

Basic Principles and Guidelines on Development-Based Environment and Displacement, which provides guidance regarding the implementation of eviction. The guide is to prevent violations of human rights caused by eviction. Thus, there are conditions that must be fulfilled by state in carrying out evictions, one of which is the implementation of eviction must be carried out in line with international human rights law. ${ }^{54}$ One form of respecting human rights in an eviction activity is the participation of affected communities. regulate forced evictions, such as an eviction is unavoidable, the action

\section{Forced Evictions Caused by Development}

The developments have caused some of the most horrific forced evictions because of the size, scale, and scope of the wider community. ${ }^{55}$ During the 1980s and 1990s, large-scale development projects resulted in the displacement of 10 million people each year. ${ }^{56}$ During the next decade, the number reached around 15 million people per year. ${ }^{57}$ Large-scale development projects that result in forced evictions are often carried out for public interest reasons. ${ }^{58}$ Such largescale development projects include the construction of dams, natural resource exploitation, and the development of expressways, and so on. ${ }^{59}$ Indigenous peoples are affected greatly by largescale development projects because they lost resources that are actually their rights, such as land, that has existed for generations. ${ }^{60}$ Large-scale development projects also cause environmental damage and loss of livelihoods, increasing the number of people who were forcibly evicted. ${ }^{61}$

In Nairobi, Kenya, evictions planned by the national government threatened around 300,000 Nairobi residents living in informal settlements. ${ }^{62}$ The government justifies the eviction; they stated that the informal settlement is located in dangerous public areas, such as under the electricity channel and on land that is provided for railroad construction reserves, or land provided for future road construction. ${ }^{63}$ Raila

Fact Sheet No. 25 (Rev.1), Forced Evictions, p. 1.

52 Paragraph 8 (a) of the CESCR General Comment No. 4: The Right to Adequate Housing reads, "all persons should possess a degree of security of tenure which guarantees legal protection against forced eviction, harassment and other threats".

53 Paragraph 14 of General Comment Number 7: The right to adequate housing "In cases where eviction is considered to be justified, it should be carried out in strict compliance with the relevant provisions of international human rights law and in accordance with general principles of reasonableness and proportionality.".
54 Paragraph 21 of the Basic Principles and Guidelines on Development-Based Evictions and Displacement.

55 UN Habitat, "Forced Evictions: Global Crisis, Global Solutions", Op.cit, p. Viii.

56 Ibid.

57 Ibid.

58 Ibid, p. Ix

59 Ibid.

60 Ibid.

61 Ibid.

62 UN Habitat, "Forced Evictions: Global Crisis, Global Solutions", Op.cit, p. 36.

63 Ibid. 
Village was the first area to be evicted. Around 400 buildings were destroyed including schools, clinics, and churches. ${ }^{64}$ The forced evictions affected around 2,000 people and it caused property losses worth millions of Kenyan shillings and were carried out without prior notice or consultation and no relocation plans were offered. ${ }^{65}$

Likewise, in the Dominican Republic, forced evictions occurred related to development projects for the sake of urbanization, covering the construction of roads or the development of land of tourism. ${ }^{66}$ Amnesty International reported that in early December 2007, a number of police and soldiers forcibly evicted 45 families, including minors, from their homes at Villa Venecia de Pantoja, about 10 kilometers from Santo Domingo. ${ }^{67}$ Police and soldiers woke the settlers around 4:00 a.m. and ordered them to leave the area immediately. ${ }^{68}$

An example of a large-scale development project is the construction of the Lyari Expressway in Karachi, Pakistan. The development is predicted to cause eviction to 77,000 families or around 230,000 people. ${ }^{69}$ This eviction would disrupt the education process of around 26,000 school students and cause 40,000 people lose their jobs. $^{70}$ The Government offered compensation and the resettlement outside Karachi but community organizations criticized it because the compensation funds was deemed inadequate, futhermore the relocation to remote areas and resulting lack of access to paved roads and other important facilities, such as water and electricity. ${ }^{71}$ Another case regarding forced evictions caused by large-scale development project is those related to indigenous peoples. ${ }^{72}$ In the Philippines, people in the Mindanao and Caraga areas have been evicted from their lands because of logging by the government permits and other development contracts, which have damaged community land caused by open pit mining. ${ }^{73}$

\section{THE PERSPECTIVE OF THE RIGHT TO DEVELOPMENT AGAINST FORCED EVICTIONS AND STATE OBLIGATION IN APPLYING THE RIGHT TO DEVELOPMENT AT NATIONAL LEVEL}

1. The Perspective of Right to Development on Forced Eviction International law prohibits forced eviction, because it causes human rights violations. However, international law does not prohibit evictions, but eviction should be a last resort, regulated by national law, respect human rights and in accordance with international standards. Fact Sheet No. 25 / Rev.1 explains the conditions that must be fulfilled by the State and one of the requirements is The rights to information and to meaningful consultation and participation should be respected at all stages of the process: $:^{74}$

Being informed about decisions of direct relevance to you and your family, having access to plans and projects, being able to meaningfully interact with the authorities and provide input in decision-making are basic human rights. In many cases, people that were supposed to be evicted were

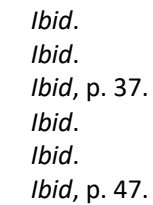


able to propose an alternative to the project and to remain where they were. If eviction is the only option, those evicted have a right to participate meaningfully in decisions on alternative housing, relocation and compensation. Indeed, States have an obligation to ensure the effective participation of and consultation with the affected communities and groups, such as IDPs (Guiding Principles 14 and 28), minorities or indigenous peoples, who have a right to participate in decisions affecting them and the regions in which they live.

The absence of participation in the eviction process is one of the causes of human rights violations. Fact Sheet Number 25/Rev.1 states that human rights violations in eviction can be direct or indirect, including related to when the eviction was decided, in the sense that the decision of the eviction involves no participation of affected individuals or communities. ${ }^{75}$ For this reason, each case of forced eviction has characteristics, including being carried out unilaterally, without involving the affected participation of communities. The fact, participation has an important role in development that results eviction. This is because participation can prevent forced eviction. The Basic Principles and Guidelines for Development-Based Evictions regulate conditions related to implementation of eviction. The Guidelines emphasize the importance of participation of affected individuals or communities because it can avoid forced eviction: ${ }^{76}$

$$
\begin{aligned}
& \text { "...All potentially affected } \\
& \text { groups and persons, including }
\end{aligned}
$$

women, indigenous peoples and persons with disabilities, as well as others working on behalf of the affected, have the right to relevant information, full consultation and participation throughout the entire process, and to propose alternatives that authorities should duly consider".

The guidelines state that participation from affected persons in during planning processes, in this case "opportunities for dialogue and consultation must be effective to the full spectrum of persons, including women and vulnerable and marginalized groups, and when necessary, through the adoption of special measures or procedures". ${ }^{77}$ In the perspective of the right to development, participation from affected person not only when States planning to eviction, but when the development is planned by the State. That is not only preventing human rights violations caused by development, such as forced evictions, but also has the possibility of preventing the occurrence of evictions. The development is seen as a right and the state should respect human rights and participation. It is based on the principle of the right to development to place human person as the central subject and the purpose of the development to realizing human rights.

Recognized development as human rights has implication not only on the occurrence of a paradigm shift related to the concept of development that is required to respect and advance human rights. However, development is an inherent right of every human being. Everyone has the right to participate, to contribute, and to receive any benefits 
of development. Article 1 Paragraph (1) of the Declaration of the Right to Development states the definition of the right to development as follows. This understanding has also opened up space to participate and to contribute to development because individuals and communities have the right to participate and contribute.

Article 2 Paragraph 1 of the Declaration on the Right to Development states "the human person is the active participant and the beneficiary of the right to development". Positioning human being as the central subject of development means that the elimination of human rights violations is an important part of development. ${ }^{78}$ This is because the enjoyment of all civil, political, economic, social, and cultural rights is an absolute requirement and goal of development. The principle of human person as the central subject also means that in the process of individual and community development, human person must be an active participant and beneficiary. For this reason, individuals or communities should not be passive recipients of development. Marks proposes this as follows. ${ }^{79}$

"In other words, recognizing development as a human right empowers all people to claim their active participation in decisions that affect themrather than merely being beneficiaries of charity-and to claim an equitable share of the benefits resulting from development gains."

Article 2 paragraph 3 states as follows.

78 Arjun Sengupta et.al, Reflections on the Right to Development, Sage Publications, New Delhi, 2005, p. 12.

79 Flávia Piovesan, Active, free and meaningful participation in development, in Realizing the Right to Development: Essays in Commemoration of 25 Years of
"States have the right and the duty to formulate appropriate national development policies that aim at the constant improvement of the well-being of the entire population and of all individuals, on the basis of their active, free and meaningful participation in development and in the fair distribution of the benefits resulting therefrom."

Participation as a part of the right to development directed to people affected by development. Hadiprayitno highlights that the effectiveness of participation must be judged subjectively based on the views of the affected people. ${ }^{80}$ The reflects whether the development is based on the desires and considerations of affected individuals and communities. Therefore, development is based on the needs and considerations of these individuals and communities. Participation can also protect the community from forced eviction. This is because in the development process, the participation is focused on the consideration of the affected people. In addition, the principle of participation is expected to protect the poor. Often, the poor is confronted to structural obstacles, which cause loss of access to participate and to contribute to the development.

In this regard, the right to development is effective to avoid violations of human rights due to the process of development. To this point, individuals or communities who are victims of human rights violations are placed as objects of development. Various cases related to forced evictions occur because individuals and

the United Nations Declaration on the Right to Development, Op.cit, p. 103.

80 Irene I. Hadiprayitno, "Poverty" in Realizing the Right to Development: Essays in Commemoration of 25 Years of the United Nations Declaration on the Right to Development, Op.cit, p. 143. 
communities are made as the objects of development. It is seen from the sense of forced eviction, namely the transfer carried out by force against the will of the displaced parties. This causes the absence of access to participate and to contribute to the development.

2. State's Obligation in Applying the Right to Development at the National Level

The role of state in implementation of the right to development is very important because it presents state as the bearer of obligations of the right of development. State has obligations that must be carried out to respect, to protect, and to fulfil human rights. In line with that, state's obligations are divided into two dimensions, namely internal and external dimensions. The internal dimension relates to the implementation of the right to development in its jurisdiction or at the national level. The external dimension is the implementation of the right to development at the international level. This study covers the internal dimensions of the right to development.

One of the weaknesses in the discourse of the right to development is state mainly focus at the international level instead of national level. ${ }^{81}$ This cannot be separated from the debate at the articulation of the right to development between third world countries and developed countries. It

81 Asbjørn Eide and Wenche Barth Eide, "Economic Globalization and the Human Rights of Poor People in Rural Areas", in Freedom from Poverty as a Human Right, Volume 3 yang disusun oleh Bård $A$. Andreassen(et.al), UNESCO Publishing, Paris, 2010, p.63.

82 The term soft law refers to an instrument that has no binding legal force. However, it does not mean that soft law has no influence in international law. In general, soft law is the source of hard law. For instance, UDHR is the source of the International Bill of Human Rights. In addition, soft law can also develop and turn into hard law, for example the Convention on the Rights of Persons with Disabilities (CRPD) which takes approximately 20 years to reform and develop from resolution and declaration. See Michael Ashley Stein* \& also related to the NIEO agenda, which influences the discourse regarding the right to development that is more focused at the international level. In addition, the instrument of the right to development in the form of soft law is another weakness to the implementation at the national level. ${ }^{82}$ However, the declaration of the right to development has a substantive relationship with other international instruments.

Furthermore, discussion to implement the right to development needs to be emphasized, ${ }^{83}$ especially at the national level. In the Declaration of the Right to Development, the role of state in the realization of the right to development is regulated in several articles that are related to each other. According to Article 3 paragraph 1, "States have the primary responsibility for the creation of national and international conditions that are favorable to the realization of the right to development". Moreover, state obligations at the national level are listed in Article 2 Paragraph 3 of the Declaration on the Right to Development as follows:

"States have the right and the duty to formulate appropriate national development policies that aim at the constant improvement of the well-being of the entire population and of all individuals, on the basis of their

Janet E. Lord, "The Normative Value of a Treaty as Opposed to a Declaration: Reflections from the Convention on the Rights of Persons with Disabilities", in Implementing the Right to Development, The Role of International Law, by Stephen P. Marks (eds), Friedrich Ebert Stiftung, Geneva, 2008, p. 27.

83 The importance of the realization and implementation of the right to development is one of the discourses among experts. For example, "Expert Meeting on legal perspectives involved in implementing the right to development" held at the Château de Bossey, Switzerland, January 4-6, 2008. They discussed legal issues related to the implementation of the right to development, including the problems and prospects for establishing binding legal standards on the right to development. 
active, free and meaningful participation in development and in the fair distribution of the benefits resulting therefrom."

The article determines that state has to participate individuals or community in the making development policies at the national level Development policies made by the state must be participatory, free, active, and meaningful. Anyone without discrimination has the right to participate, especially individuals or communities affected by the development policy.

The most important element on the success of policy is the adoption of appropriate development strategies that aim to promote human rights. ${ }^{84}$ The declaration of the right to development does not mention a specific development model that can be implemented by state. The absence of the concept demonstrates its ability to adapt to the different models in each country. According to Alston, this is "open ended and indeterminate", because the Declaration shows dynamism to adapt to various circumstances. ${ }^{85}$

The report of the Secretary-General also states that there is no universal model of development process. $^{86}$ However, the Report states that effective development strategies, both at national and international levels, must be based on respect to human rights and include measures to realize the rights. ${ }^{87}$ Thus, each development model must lead to the realization of the right to development for each individual and everyone. In this case, development must be a process that leads to the realization of human rights.

One of the influences of the right to development on the concept of development is the change of the notion of

84 Report of the Global Consultation on the Right to Development as a Human Right, "The challenge of implementing the right to development in the 1990s" in Realizing the Right to Development: Essays in Commemoration of 25 Years of the United Nations Declaration on the Right to Development, Op.cit, p. 54.

85 Alston in Khursid Iqbal, Op.cit, p. 90.

86 Report of the Secretary-General, "The Emergence of The Right to Development", in Realizing the Right to development to be holistic. It does not cover only economic growth but also relates it to the discourse of human rights. This characterizes an acknowledgment of the fact that human rights and development policies are interrelated. ${ }^{88}$ Based on this, development is no longer seen only in terms of national income growth or even per capita income. ${ }^{89}$ This definition describes development not only as an economic process but also social, cultural, and political as well as outlining several principles related to development, such as development goals to improve welfare, placing humans as the central subject of development, and equitable distribution related to the results of development. In addition, the Declaration of the Right to Development also recognizes the importance of respecting and promoting human rights.

The Declaration of the Right to Development states that the implementation of the right to development must respect human rights completely, either civil and political rights; and economic, social, and cultural rights. This is because the Declaration of the Right to Development expressly acknowledges the inseparability, interdependence, and relevance of human rights, as an expression of the idea of the unity of human rights in the right to development. Iqbal says that the Declaration of the Right to Development has set guidelines to achieve development goals, as contained in Article 8 of the Declaration as follows. ${ }^{90}$

Iqbal's view is related to the purpose of development, not the process of development. In addition, the Article 8 paragraph 1 of the Declaration of the Right to Development has relevance to the

\footnotetext{
Development: Essays in Commemoration of 25 Years of the United Nations Declaration on the Right to Development, Op.cit, p. 8.

88 Khursid Iqbal, Op.cit, p. 8.

89 Report of the Secretary-General,, Op.cit, p. p. 8.

90 Khursid Iqbal, Op.cit, hlm. 89.
}

87 Ibid. 
principles in other human rights instruments. This is as stipulated in Article 11 of the ICESCR on the decent standard of living guaranteed for each individual and his family, as well as for continuous improvement of living conditions. ${ }^{91}$ One of the elements in a decent standard of living is the right to adequate housing. ${ }^{92}$ Hence, state must take adequate steps to guarantee the realization of this right. ${ }^{93}$

The Article 6 of the Declaration of the Right to Development recognizes that human rights are indivisible. Therefore, development must respect human rights as a whole, both civil and political rights; and economic, social, and cultural rights. The right to development proclaims the unity of the two forms of human rights: civil and political rights; and economic, social, and cultural rights. In addition, Development must not lead to denial of other human rights. There is a strict statement in the Declaration of the Right to Development that mentions the promotion of, respect for, and rights of fundamental rights and freedoms. ${ }^{94}$

In the implementation the right of development, state must be able to guarantee that the distribution of the benefits of development is fair and there is no harm caused by development. The failure of the State to guarantee the absence of negative effects from development that harms individuals or community, shows the failure of state to fulfill a fair distribution of the benefits of development. Special attention must be given to vulnerable groups. Although there is no definite category related to vulnerable groups, ${ }^{95}$ in terms of development, the poor are often the victims of right violation. In addition, as a vulnerable group, the poor

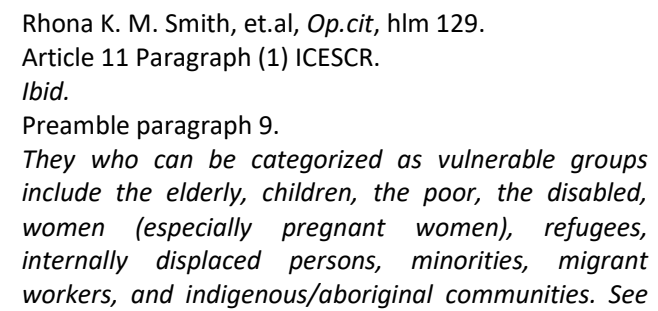

often are marginalized and unable to enjoy their rights, including the right to development. ${ }^{96}$

This special attention expected to improve their quality of life, so that development becomes more meaningful. This is because poverty is related to the right to development. There is an assumption that one of the causes of poverty is denial of human rights. ${ }^{97}$ Although the declaration of the right to development does not explicitly address the special attention to vulnerable groups (the poor), some principles of the Declaration, such as fair distribution, participation, ${ }^{98}$ contribution to and enjoy economic, social, cultural, and political developments ${ }^{99}$, are an indication that the right to development is an effective tool to reduce inequality and poverty. This is because poverty is caused not only by natural resources, but also by structural problems.

Based on the description, state obligation to implement the right to development is not only related to the results but also the processes of development. Both are interrelated and complementary. This not only protects individuals or communities from human rights violations, because of development, but also provides hope for vulnerable groups (especially the poor) to engage and participate in the development process, additionally to enjoy the results and the benefits of development based on fair distribution to improve their standard of living.

To realizing the right of development, state must create conditions that support the promotion of participation as an important factor in the development process and the fulfillment of human rights.

\footnotetext{
the National Human Rights Commission [Komisi Nasional Hak Asasi Manusia], Pembangunan Berbasis Hak Asasi Manusia: Sebuah Panduan, Jakarta, Komisi Nasional Hak Asasi Manusia (Komnas HAM), 2013, p. 79.

99 Article 1 of the Declaration of the Right to Development.
} 
Participation has become an integral part of development and an important principle of the development process. Article 1 paragraph 1 of the Declaration of the Right to Development states that individuals and communities have the right to participate in development process. Then, Article 2 paragraph 3 states as follows.

"States have the right and the duty to formulate appropriate national development policies that aim at the constant improvement of the well-being of the entire population and of all individuals, on the basis of their active, free and meaningful participation in development and in the fair distribution of the benefits resulting therefrom."

Article 8 paragraph 2, "States should encourage popular participation in all spheres as an important factor in development and in the full realization of all human rights." The Declaration on the Right to Development give special attention to women, Article 8 paragraph 1 states "...women have an active role in the development process."

Therefore, democracy and political freedom should include at national level participation. According to Piovesan, participation at the national level must be carried out based on democratic principles, such as equality and non-discrimination based on gender, race, ethnicity, and other criteria, paying special attention to the most vulnerable. ${ }^{100}$ Those principles refer to the component of development proposed by Sen that democracy and political freedom are important factors in development process. ${ }^{101}$

The Vienna Declaration and Program of Action (1993) also mention the linkages between development, democracy, and freedom. These three elements are interdependent and strengthen each other. ${ }^{102}$ The Vienna Declaration and Program of Action (1993) explains that

100 Flávia Piovesan," Op.cit, p. 105.

101 Ibid.

102 Article 8 of the Vienna Declaration and Programme of Action (1993) "democracy is based on the determination of a nation that is expressed freely to establish their own political, economic, social and cultural systems and their full participation in all aspects of life". ${ }^{103}$ Furthermore, it is stated that the international community must support in strengthening and promoting democracy, development, and human rights and fundamental freedoms throughout the world. ${ }^{104}$

\section{E. CONCLUSION}

The principles contained in the right to development can prevent forced eviction. The displacement of individuals or communities is caused by their positioning as objects of development, which results in the closed space of participation in development. Tensure the principles of the right to development are fulfilled, the role of state is needed as the carrier of the right to development. However, one of the problems related to the implementation of the right to development is the legal instrument, namely the Declaration of the Right to Development that does not legally binding. Apart from this, the fulfillment of the right to development has profound influence on third world countries and gives hope for vulnerable groups to be able to get involved and receive benefits from development.

\section{REFERENCES}

\section{Books}

Eide, Asbjørn dan Barth Eide, Wenche, "Economic Globalization and the Human Rights of Poor People in Rural Areas", dalam buku Freedom from Poverty as a Human Right, Volume 3 yang disusun oleh Bård A. Andreassen (et.al), UNESCO Publishing, Paris., 2010. 
Irene I. Hadiprayitno, "Poverty" in Realizing the Right to Development: Essays in Commemoration of 25 Years of the United Nations Declaration on the Right to Development, United Nations Publication, New York and Geneva, 2013.

Iqbal, Khursid, The Right to Development in International Law: The Case of Pakistan, Routledge Research in Human Rights Law, Abingdon, 2009.

Macklem, Patrick, The Sovereignty of Human Rights, Oxford University Press, New York, 2015.

Piovesan, Flávia, "Active, free and meaningful participation in development" in Realizing the Right to Development: Essays in Commemoration of 25 Years of the United Nations Declaration on the Right to Development, United Nations Publication, New York and Geneva, 2013.

Sengupta, Arjun, "Conceptualizing the right to development for the twenty-first century" in Realizing the Right to Development: Essays in Commemoration of 25 Years of the United Nations Declaration on the Right to Development, United Nations Publication, New York and Geneva, 2013.

(et.al), Reflections on the Right to Development, Sage Publications, New Delhi, 2005.

Smith, Rhona K. M., et.al, Hukum Hak Asasi Manusia, PUSHAM UII, Yogjakarta, 2008.

Stein, Michael Ashley \& Lord, Janet E, "The Normative Value of a Treaty as Opposed to a Declaration: Reflections from the Convention on the Rights of Persons with Disabilities", dalam buku Implementing the Right to Development, The Role of International Law, yang disusun oleh Stephen P. Marks (eds.), Friedrich Ebert Stiftung, Geneva, 2008.

\section{Other Documents}

Atip Latipulhayat, "Merawat Hak Asasi Manusia", Editorial Padjadjaran Jurnal
Ilmu Hukum, Volume 1 No 2, Agustus 2014.

Irawati Handayani, Justiciability of Economic, Social and Cultural Rights in International Law and Its Implementation in Indonesia, Jurnal Yustisia, Vol. 7 No. 3, 2018.

Komisi Nasional Hak Asasi Manusia, 2013, Pembangunan Berbasis Hak Asasi Manusia: Sebuah Panduan, Jakarta, Komisi Nasional Hak Asasi Manusia (Komnas HAM). https://www.komnasham.go.id/files/20 131117-pembangunan-berbasis-hakasasi-\$SLP7PE.pdf.

Langford, Malcolm and du Plessis, Jean, "Dignity in the Rubble? Forced Evictions and Human Rights Law", https://www.jus.uio.no/ior/english/peo $\mathrm{ple} / \mathrm{aca} / \mathrm{malcolml} /$ dignity-in-the-rubble--human-rights-law-and-forcedevictions.pdf.

Report of the Global Consultation on the Right to Development as a Human Right, "The challenge of implementing the right to development in the 1990s" dalam dalam buku Realizing the Right to Development: Essays in Commemoration of 25 Years of the United Nations Declaration on the Right to Development, United Nations Publication, New York and Geneva, 2013.

Report of the Secretary-General, "The emergence of the right to development", dalam buku Realizing the Right to Development: Essays in Commemoration of 25 Years of the United Nations Declaration on the Right to Development, United Nations Publication, New York and Geneva, 2013.

Sengupta, Arjun, "On the Theory and Practice of the Right to Development", Human Rights Quarterly, Vol. 24, No. 4, 2002.

Taznara Kunanayakam, "Annotations to the Declaration on the Right to Development and related United Nations system instruments, resolutions 
and reports" (HR/RD/1990/ CONF.1), Global Consultation on the Realization of the Right to Development as a Human Right.

UN Habitat, "Forced Evictions: Global Crisis, Global Solutions", A Review of the Status of Forced Evictions Globally Through the Work of the Advisory Group on Forced Evictions, Un Habitat and Other International Actors,

http://hrbaportal.org/wpcontent/files/Forced-Evictions- -UNHabitat.pdf.

Van der Have, Nienke,"The Right to Development and State Responsibility", Amsterdam Law School Legal Studies Research Paper No. 2013-23.

\section{Legal Documents}

Basic Principles and Guidelines on Development-Based Evictions and Displacement CESCR General Comment No. 4: The Right to Adequate Housing Declaration on the Right to Development Fact Sheet No.25/Rev.1, Forced Evictions Forced evictions, Commission on Human Rights resolution 1993/77

Frequently Asked Questions on the Right to Development, (Fact Sheet No. 37)

International Covenant on Civil and Political Rights

International Covenant on Economic, Social and Cultural Rights

Prohibition of Forced evictions, Commission on Human Rights Resolution: 2004/28

The Right to Adequate Housing (Art.11.1): forced evictions: .20/05/97.

The Right to Adequate Housing, Fact Sheet No. 21/Rev.1

CESCR General comment 7. (General Comments)

Vienna Declaration and Programme of Action (1993) 